\title{
The Effect of Ketogenic Diet Treatment in Drug-resistant Epilepsies of Childhood
}

\author{
Çocukluk Çă̆ı Dirençli Epilepsilerinde Ketojenik Diyet Uygulamalarının Etkisi
}

\author{
(1) Gizem Özata Uyar, (1) Nevin Şanlıer \\ Gazi University Faculty of Health Sciences, Department of Nutrition and Dietetics, Ankara, Turkey
}

\begin{abstract}
Epilepsy is an important health issue. The interest in ketogenic diet (KD) treatment in children and adolescents with drug-resistant epilepsy has increased in recent years. It was thought that KD was a last option of treatment in patients who were unresponsive to 2 or 3 anticonvulsant drugs. KD with limited protein, low carbohydrate, and high fat content was thought as a last option of treatment, previously. However, nowadays it is the most selected therapy worldwide in epileptic children and adolescents. Ketone bodies are elevated in the blood due to low carbohydrate and high lipid content of KD. Through the elevation of ketone bodies, the brain uses ketone bodies as energy sources, which results in decreased in epileptic seizures. Medical nutritional therapy during treatment of childhood epilepsies should also provide normal growth and development. For this reason, full compliance with the diet is important. The effect, place, and importance of ketogenic nutrition therapy in drug-resistant epilepsies of childhood are discussed in this review.
\end{abstract}

Keywords: Childhood, drug-resistant epilepsy, ketogenic diet

Öz

Epilepsi önemli bir sağlık sorunudur. Son yıllarda dirençli epileptik çocuk ve adölesanlarda ketojenik diyet (KD) uygulamalarına olan ilgi giderek artmaktadır. KD 2-3 çeşit antikonvülzan ilaçla nöbet kontrolü sağlanamadığı durumlarda son çare tedavi yöntemi olarak düşünülmektedir. Proteinden sınırlı, düşük karbonhidrat ve yüksek yă̆ içeriğine sahip KD uygulamaları daha önceleri son çare olarak uygulanırken günümüzde sıklıkla kullanılan bir tedavi haline gelmiştir. Diyetteki karbonhidrat içeriğinin düşük ve yă̆ içeriğinin yüksek olması nedeniyle kanda keton cisimlerinin artışı söz konusudur. Keton cisimlerinin artı̧̧ıla beyin keton cisimlerini enerji kaynağ1 olarak kullanmakta ve epileptik nöbetlerde azalma görülmektedir. Çocukluk döneminde epilepsi tedavisi süresince yapılan beslenme tedavisi normal büyüme ve gelişmeyi sağlamalıdır. Bunun için de diyete uyumun tam olması oldukça önemlidir. Bu derlemede çocukluk çă̆ dirençli epilepsilerinde KD'nin etkisi, yeri ve önemi irdelenmiştir.

Anahtar Kelimeler: Çocukluk çă̆ı, ilaca dirençli epilepsi, ketojenik diyet

\section{Introduction}

\section{Ketogenic Diet}

Epilepsy, one of the most common neurologic disorders of childhood, is complicated with pharmacoresistance in one-quarter of all patients. Seizures cause delay cognitive and psychosocial development and prevent reaching normal developmental capacity in children in whom neuronal differentiation is not yet completed (1). Ketogenic diet (KD) is the last treatment option in patients whose seizures are resistant to 2 or 3 anticonvulsant drugs (2).

The classic KD, which was developed in the 1920s, has been effectively used in patients with drug-resistant epilepsy (3). KD is known as "long chained triglyceride" diet, which has limited protein, low carbonhydrate, and high fat content (4). Most of the energy gathered by feeding comes from fats. Protein intake is kept in the lower limit of requirements and carbohydrate intake is severely restricted (5).

The ratio of fat to carbohydrate and protein is determined as 4:1 in terms of grams in the classic form of KD. Ninety percent of the energy is gathered from fats and $10 \%$ from carbohydrates and proteins (6). In such a diet, to provide enough protein, ratios of $3: 1$ (86\% fats) and 2:1 (83\% fats) are prefered in adolescents, children, and infants. KD is prefered in children aged above 1 year because children aged below 1 year are more prone to hypoglycemia (2).

Address for Correspondence/Yazışma Adresi: Gizem Özata Uyar, Gazi University Faculty of Health Sciences, Department of Nutrition and Dietetics, Ankara, Turkey Phone: +905539275027 E-mail: gizemozata91@gmail.com ORCID ID: orcid.org/0000-0002-9022-6956

Received/Geliş Tarihi: 25.04.2016 Accepted/Kabul Tarihi: 02.10.2016

${ }^{\oplus}$ Copyright 2018 by Turkish Neurological Society

Turkish Journal of Neurology published by Galenos Publishing House. 
KD causes production of ketone bodies in the liver, which is its most important feature. Ketone bodies are used as an alternative fuel to glucose for energy and brain development (7). A decrease in serum glucose levels causes $\beta$-oxidation of the fatty acids leading to the production of ketone bodies (acetone, acetoacetate, $\beta$-hydoxybutyrate). Ketone bodies take place in brain development, cell membranes, and lipid biosynthesis besides serving as energy substrates (8).

$\mathrm{KD}$ is considered as one of the most effective treatment options in epilepsies of childhood (5). The energy and nutrients of a KD should be calculated individually (4). Fluid restriction has not been recommended in recent years because sufficient fluid intake prevents dehydration and plays protective roles against constipation and kidney stone formation (5).

\section{Indications and Contraindications of the Ketogenic Diet}

KD has been used for years in patients who are not appropriate for epilepsy surgery and who are refractory to conventional antiepileptic drugs (9). There are special conditions in which KD can be beneficial and also there are contraindications for KD (5). The indications and contraindications of KD are shown in Table 1 (2). Fat is used as a source of energy instead of carbohydrate in $\mathrm{KD}$, which can cause serious problems if $\mathrm{KD}$ is used in disorders of lipid metabolism. For this reason, children should be screened for disorders of fatty acid oxidation and transportation before the initiation of KD (2).

\section{Mechanisms of Action of Ketogenic Diet}

The mechanisms of action of KD are not well known (5) but multiple mechanisms are considered to take place in suppressing seizures (10). These mechanisms are:

Importance of ketone bodies: Clinical evaluations of patients who are on $\mathrm{KD}$ are performed due to $\beta$-hydroxybutyric acid (BHB) levels in serum. Studies have tried to find a causal relationship between ketonemia and the anticonvulsant effect. Although high serum levels of $\mathrm{BHB}$ were achieved with $\mathrm{KD}$ $(7,11)$, no relationship could be found between BHB levels and seizure control (8). However, in a study performed on mice with Dravet syndrome, higher BHB serum levels were achieved in mice on a KD compared with mice with a standard diet and a better seizure control was achieved in mice on KD (12).

KD with a higher ratio of fat (6:1) was used in mouse models and resulted in better outcomes (ignoring the toxic effects) (13). The modified Atkins diet (MAD) and low glycemic index treatment (LGIT) were shown to have similiar effects with KD, but they resulted in less ketosis. High levels of ketosis are not considered as the main mechanism in humans $(14,15,16,17)$.

Role of polyunsaturated fatty acids (PUFA): PUFAs including docosahexaenoic acid (DHA) and arachidonic acid are related with cardiovascular functions (7). Recent studies have focused on PUFAs. After KD, serum and brain levels of PUFAs including DHA and arachidonic acid were shown to increase (18). PUFAs are thought to modulate neuronal membran excitability by

\section{Table 1. Indications and contraindications of the ketogenic diet (2)}

Probable benefits (at least two publications)

GLUT-1 deficiency

PDHD

Myoclonic astatic epilepsy (Doose syndrome)

Tuberous sclerosis complex

Rett syndrome

Severe myoclonic epilepsy of infancy (Dravet syndrome)

Infantile spasms

Children only receiving formula (infants or enteral feeding patients)

\section{Possible benefits}

Some mitochondrial disorders

Glycogenosis type 5

Landau Kleffner syndrome

Lafora's disease

SSPE

\section{Absolute contraindications}

Primary carnitine deficiency

CPT 1 or 2 deficiency

Carnitine translocase deficiency

\section{Oxidation defects}

Medium-chain acyl-CoA dehydrogenase deficiency (MCAD)

Long-chain acyl-CoA dehydrogenase deficiency (LCAD)

Short-chain acyl-CoA dehydrogenase deficiency (SCAD)

Long-chain 3-hydroxyacyl-CoA dehydrogenase deficiency

Medium-chain 3-hydroxyacyl-CoA dehydrogenase deficiency

Pyruvate carboxylase deficiency

Porphyria

\section{Relative contraindications}

Difficulty in maintaining adequate nutrition

Surgical focus identified by neuroimaging and video EEG monitoring

Parent or caregiver noncompliance

GLUT-1: Glucose transporter-1, PDHD: Pyruvate dehydrogenase deficiency, SSPE: Subacute sclerosing panencephalitis, CPT: Carnitine palmitoyl transferase, CoA Coenzyme, EEG: Electroencephalography 
stabilizing voltage-gated sodium and calcium channels (10). Some studies showed higher arachidonic acid levels provide seizure control, whereas others showed no relationship between high level of PUFAs and seizures. The anticonvulsant effects of PUFAs are under research $(19,20,21)$. Fatty acids modulate uncoupled mitochondrial protein expression and activation. Activation of mitochondrial uncoupled proteins causes a decrease in the proton gradient against the inner mitochondrial membrane, which leads to a decrease in the production of free oxygen radicals. A decrease in the production of free oxygen radicals can prevent epileptic activity (22).

Anti-inflammatory effects and protection from excitotoxicity: KD has anti-inflammatory effects and provides protection from excitotoxicity-induced neuronal death. Glutamate toxicity in the hippocampus is held responsible for neuronal damage. It is suggested that KD reduces this toxicity (10).

Neurometabolites and changes in their receptors: KD affects seizure control by changing neurometabolite levels. In vivo studies have shown that high levels of BHB increase synthesis of cerebral kynurenic acid (endogenous antagonist of glutamate), which has anticonvulsant effects (23). Another study showed that acetoacetate and BHB were affected by increasing transamination of glutamate to aspartate and conversion to gamma-aminobutyric acid (10).

Positive energy balance: It was shown that when rats were on $\mathrm{KD}$, total levels of bioenergic substrates (i.e ATP) were increased and cell membranes were stabilized, which provided protection in conditions requiring high energy such as seizures (10).

Antioxidant mechanisms: Ketone bodies prevent formation of free radicals by decreasing coenzyme Q10 levels. Also, ketone bodies prevent lipid peroxidation by increasing the activity of glutathione peroxidase in the hippocampus of rats (10).

\section{Efficacy of Ketogenic Diet}

The efficacy of KD in drug-resistant childhood epilepsies has been shown in retrospective and prospective studies and meta analyses $(5,24,25,26,27)$. Eleven studies regarding the efficacy of KD in children with drug-resistant epilepsy were evaluated in a systematic review. Seizure freedom was achieved in $16 \%$ of patients. There was more than a $90 \%$ reduction in seizures in $32 \%$ of patients and more than a $50 \%$ reduction in seizures in $56 \%$ of the patients (5). A Cochrane review evaluated 4 randomized and controlled studies (28,29,30,31). The efficacy of KD on seizures was investigated in 289 children and adolescents in these studies. It was concluded that KD reduced the frequency of seizures in short and medium terms in children (25). Nineteen studies including 1084 children (mean age at initiation $5.78 \pm 3.43$ years) were evaluated in a meta-analysis by Henderson et al. (27). There was $>90 \%$ seizure reduction in one-third of patients and $>50 \%$ seizure reduction in half of the patients. A study from China showed that after 3, 6 and 12 months, $35 \%, 26.2 \%$, and $18.6 \%$ of 317 children with refractory epilepsy on $\mathrm{KD}$ showed $>50 \%$ seizure reduction, respectively (32). Keene (26) found that after initiation of KD, $15.6 \%$ of patients became seizure free, and there was $>50 \%$ seizure reduction in $33 \%$ of patients. Twenty-seven children with refractory epilepsy were included in a prospective study from India. Fifty-five percent remained on KD at 6 months, and $37 \%$ remained on it at 1 year. Fourty-eight percent had $>50 \%$ reduction in seizures, and four children (15\%) were seizure free at 6 months. At 1 year, $37 \%$ had $>50 \%$ reduction in seizures and five children (18.5\%) were seizure free (33). In another study, 61 children with refractory epilepsy were given KD; 29 (48\%) were responders at 3 months. Two children became seizure free beginning from the second month and stayed seizure free for 2 years. Twenty-four $(42 \%)$ of the patients were responders at 6 months (34). KD was used in 10 children with refractory focal status epilepticus for 6 months. Seizures stopped in two patients and five patients had a $50-75 \%$ seizure reduction within 5-7 days following the onset of the diet. Three patients had a $<50 \%$ seizure reduction; however, they all had severe adverse events so the diet was discontinued. Seven patients remained on the diet for 6 months to 3 years (mean 1.5 years), in whom the seizures recurred within 4 months, but their quality of life did not worsen (35). In a study, the efficacy of KD in 58 infants $<1.5$ years of age and 57 children $>1.5$ years of age were evaluated. The rates of seizure freedom were $34.5 \%$ and $32.7 \%$ in infants; $19 \%$ and $17.5 \%$ in children at 3 and 6 months, respectively (36).

$\mathrm{KD}$ is shown to be more effective than most antiepileptic drugs and to reduce seizure frequency at least by $50 \%$ in half of the patients (4). KD is a good treatment option in refractory epilepsies. Also after discontinuation of $\mathrm{KD}$, recurrence rate of seizures is reduced. However, there insufficient studies to show the effects of KD on health with long-term use (37).

\section{Preparation Before the Diet}

After initiating $\mathrm{KD}$, patients should be monitored and as a result, consulting services are important. By monitoring the laboratory findings, the nutrition program should be edited (Table 2). KD has to be initiated after training the family. Patients with epilepsy with unknown etiology should be screened for metabolic diseases and families should be informed and checked for kidney stones, which are possible complications of KD. Adapting the diet is very important and all family members (including siblings and elders such as grandmothers) should be trained (4). Dietitians/nutritionists should determine the patient's daily energy and nutrient needs by reviewing the anamnesis of the patient's growth and nutrition. Children with severe neurologic impairment should be evaluated for swallowing and chewing abilities and gastroesophageal reflux (5). The diet should be prepared by considering the family's food preferences, socio-cultural and economic status. Drugs containing carbohydrates should be replaced with carbohydratefree treatments (4). Several tests are suggested before starting KD (Table 2) (2).

\section{The Initiation of the Ketogenic Diet}

The dietitian and the physician should determine the composition of the diet, the content of liquid, the energy and the ratio of $\mathrm{KD}$. Before initiating $\mathrm{KD}$, a careful anamnesis should be taken. The main protocol of KD is to start with fasting (4). Carbohydrate intake should be limited on the day before initiating 
ketogenic feeding (38) and low carbohydrate intake should be achieved for 24 hours. Children should be examined when they are admitted to the clinic and the fasting period should be initiated in the evening (39).

In the initiation of ketogenic feeding, the patient's serum level of glucose should be checked every 6 hours and the patient should be allowed to drink water. If serum glucose levels decrease to the level of $25-40 \mathrm{mg} / \mathrm{dL}$ and the patient is not symptomatic (severe lethargy or vomiting), then no treatment is recommended $(4,38)$. If the patient becomes symptomatic, $30 \mathrm{~mL}$ of orange juice is given and serum glucose levels are checked (4). For the initiation of ketogenic feeding, the most common used protocol in the world, The Johns Hopkins Medical Institution's protocol, should be used. According to this protocol;

1. day; while fasting continues at hospital, fluids are restricted to $60-75 \mathrm{cc} / \mathrm{kg}$. Blood glucose is monitored every 6 hours, carbohydrate-free drugs are used and parents begin an educational program.
2. day; dinner is given as "eggnog" as a third of calculated diet meal. Blood glucose checks are discontinued after dinner. Parents begin to check urine ketones periodically.

3. day; breakfast and lunch are given as a third of diet. Dinner is increased to two-thirds (still eggnog). Education program is completed.

4. day; breakfast and lunch are given as two-thirds of diet allowance. Dinner is first full ketogenic meal (not eggnog).

5. day; full KD breakfast is given. Prescriptions are reviewed and follow-up is arranged. Child is discharged to home (39).

Fasting for 36 hours or ketone positivity in urine should be achieved. On the first day of ketogenic feeding, one-third of the total energy; on the second day two-thirds of the total energy, and on the third day, all of the energy should be provided. Patients can be discharged on the fifth day $(4,38)$.

Bergqvist et al. (40) showed that there was no need to start $\mathrm{KD}$ with fasting in children. They showed performing KD gradually reduced the frequency of seizures and reduced adverse

\section{Table 2. Recommendations for pre-ketogenic diet evaluation* (2)}

\section{Counseling}

Discuss seizure reduction, medication, and cognitive expectations

Identify potential psychosocial barriers to the use of ketogenic diet

Review anticonvulsants and other medications for carbohydrate content

Recommend family read parent-oriented ketogenic diet information

\section{Laboratory evaluation}

Complete blood count

Electrolytes to include serum bicarbonate, total protein, calcium, zinc, selenium, magnesium, and phosphate

Serum liver and kidney tests

(including albumin, AST, ALT, BUN, creatinine)

Fasting lipid profile

Serum acylcarnitine profile

Urinalysis

Urine calcium and creatinine

Anticonvulsant drug levels (if applicable)

Urine organic acids

Serum amino acids

\section{Nutritional evaluation}

Baseline weight, height, and ideal weight for stature

BMI when appropriate

Nutrition intake history: 3-day food record, food preferences, allergies, aversions, and intolerances

Establish diet formulation if it is necessary: oral, enteral or a combination

Decision on which diet to begin (MCT, classic, modified Atkins, or low glycemic index)

Calculation of calories, fluid, and ketogenic ratio (or percentage of MCT oil)

Establish nutritional supplementation products based on dietary reference intake

\section{Ancillary testing}

Renal ultrasound and nephrology consultation (if a history of kidney stones)

EEG

MRI

Cerebrospinal fluid (if no clear etiology has been identified)

ECO if history of heart disease

BMI: Body mass index, MCT: Medium chain triglyceride, ALT: Alanine aminotransferase, AST: Aspartate aminotransferase, BUN: Blood urea nitrogen, ECO: Echocardiogram, EEG: Electroencephalography, MRI: Magnetic resonance imaging

*Parameters that should be checked at least once every three months in the first year of the implementation of ketogenic diet 
events. They also showed that starting KD gradually without fasting provided easier implementation of $\mathrm{KD}$, shorter periods of hospital stay, and lower expenses. Without fasting, all of the energy can be provided by $1: 1$ (fat: carbohydrate + protein) KD initially and ratios can be increased daily to $2: 1,3: 1$ and finally $4: 1$ (4). On the other hand, starting KD with fasting has important advantages. Fast onset causes production of ketone bodies faster and has advantages in determining what is behind the metabolic disorder. Patients must be hospitalized if fasting will be used and families can be trained to perform KD during their stay at hospital (41). Some authors think that a decrease in frequency of seizures initially, mimics the response to an intravenous loading dose of an anticonvulsant drug (38). The disadvantages of fasting are physiologic stress, risk of hypoglycemia and dehydration, improper hospital conditions, increased expenses, and repeated blood tests. 'Intermittent fasting' was used with KD in pediatric patients in whom seizures were not well controlled and a temporary improvement in the frequency of seizures was reported (42).

\section{Calculation in Classic Ketogenic Diet}

In $\mathrm{KD}$ treatment, while calculating individual energy and nutrient demands, ketosis should be maintained but also growth and development should be achieved. A high energy-containing diet causes a rapid increase in weight, whereas a low energy-containing diet results in insufficient ketosis and growth retardation. Fast increases and decreases in weight should be avoided (43). When energy need is being calculated, food consumption records, body weight, height, physical activity status, seizure frequency, and drug use should be considered (6). When calculating daily energy need in children, "weight to height" is the main parameter. If the child has low weight, the current body weight should be used as the initial target of energy. If the child is overweight, then a calculation with a value that is close to "height to weight" is more accurate (43).

\section{Determining the Ketogenic Diet Ratio}

The ratio of $\mathrm{KD}$ means the ratio of fats to carbohydrates and proteins (43). It is 3:1 KD in adolescents and infants, in other childhood periods, 4:1 KD are used initially (44). To support protein needs in children aged below 2 years who have a high speed of growing and adolescents, $\mathrm{KD}$ with a low ratio is recommended $(43,45)$. Total energy requirement is divided by energy in a diet unit, and as a result, the daily number of diet units is gathered. Total carbohydrate, protein, and fat levels in grams are calculated according to the level of daily recommendations and then divided equally into three or four meals. The fourth meal is organized according to the 'snack-liking status' of the patient. In every meal, the ratio of KD should remain constant (10). Ratios of KD are intended to better regulate the degree of ketosis and higher ratios of KD results in better ketosis $(43,44,46)$. Same ratios of KD may result in different ketosis levels even in two individuals with same age and weight due to differences in energy metabolisms (43). A study evaluating the efficacy of different $\mathrm{KD}$ ratios included 38 children who were divided into two equal groups. One of the groups received 4:1 KD and the other group received 2.5:1 KD. Seizures were reduced by more than $50 \%$ in each group. It was concluded that low-ratio KD was as efficient as high-ratio $\mathrm{KD}$ and might have lower rates of adverse events. Seo et al. (31) evaluated the differences between $3: 1$ and 4:1 KD in children with drug-resistant epilepsy and found a better antiepileptic effect with 4:1 KD. Although children in the 4:1 KD group had remissions, children in the 3:1 KD group tolerated it better due to having fewer gastrointestinal symptoms. Classic KD units are shown below (Table 3) (43).

Example: Calculation of total diet unit in a patient who has an energy need of $1300 \mathrm{kcal}$ daily and who is determined to receive 4:1 KD: $1300 / 40=32.5$

\section{Calculation of the Amount of Fat That Needs to Be Taken with the Diet}

Multiplication of the total diet units and the ratio of KD gives the amount of fat that needs to be taken with $\mathrm{KD}$ in terms of grams.

Example: If the total diet units is 32.5 and the ratio of $\mathrm{KD}$ is $4: 1$, then the amount of fat that needs to be taken with $\mathrm{KD}$ is $32.5 \times 4=130$ grams (43).

\section{Calculation of Daily Carbohydrate and Protein Needs}

While performing $\mathrm{KD}$, it is important to meet the need for protein, which is used for growth and building tissues. The calculation of protein need is made on a daily receipt index (DRI). The multiplication of total diet units and the ratio of KD gives the total amount of carbohydrate and protein need. If the amount of protein is removed from the total amount of carbohydrate and protein, then the amount of carbohydrate need is calculated.

Example: Daily protein need of 7-year-old child who is $23 \mathrm{~kg}$, is: $23 \mathrm{kgx} 0.95 \mathrm{~g} / \mathrm{kg}(\mathrm{DRI})=22 \mathrm{~g} /$ day. 32.5 (total diet unit) $\mathrm{x} 1$ (KD

\begin{tabular}{|llll|}
\hline Table 3. Classic ketogenic diet units (43) & & Fats (g) in each \\
\hline Ketogenic diet ratios & $\begin{array}{l}\text { Energy (kcal) values of } \\
\text { each unit }\end{array}$ & $\begin{array}{l}\text { Carbohydrates + proteins } \\
\text { (g) in each diet unit }\end{array}$ \\
$2: 1$ & 22 & 2 & 1 \\
$3: 1$ & 31 & 3 & 1 \\
$4: 1$ & 40 & 4 & 1 \\
$5: 1$ & 49 & 5 & 1 \\
\hline
\end{tabular}


ratio) $=32.5 \mathrm{~g}$ (total amount of carbohydrate and protein). When the protein need of the child is removed from the total amount of carbohydrate and protein, then the daily carbohydrate need is calculated: $32.5-22=10.5 \mathrm{~g}(43)$.

\section{Alternatives of Ketogenic Diet}

There are different methods that are used to prevent the adverse events of classic KD. Alternative diets including the MAD, medium chain triglyceride (MCT) diet, and LGIT allow more energy, liquid, and protein uptake (5). KDs are shown to be more effective than any new antiepileptic drugs in treating patients with refractory epilepsy. A meta-analysis showed the MAD and LGIT resulted in less ketosis but their efficacies were similiar to that of classic KD (10).

\section{Medium Chain Triglyceride Diet}

The MCT diet has been used since 1970 as another source of fat (47). MCTs produce more ketone bodies than long chain triglycerides (LCT) $(28,48,49)$. Carnitine is used in the transportation of long chain fats to mitochondrial membranes; medium chain fats (C:6-12) do not require carnitine. The differences in the metabolism of MCTs result in faster and more oxidation. Number of ketone bodies per energy is higher in MCT-based diets compared with long chain fatty acid diets (50). The calculation is based on the ratio in classic KD, whereas it is through percentage in the MCT diet (48). In the treatment of epilepsy, $60 \%$ of energy is provided by MCTs $(48,49)$. High amounts of MCTs cause gastrointestinal adverse events, abdominal cramps, diarrhea, and vomiting in children, which limit its use in children with refractory epilepsy $(6,48,49)$. In studies, $30 \%$ of energy is provided by MCTs and another $30 \%$ is provided by LCTs. It was shown that $40-50 \%$ of the total energy need should be provided by MCTs for better gastrointestinal tolerance and ketosis $(6,49,51)$. MCTs can be given as fat or emulsion liquid in diet. MCTs can be included in all meals and snacks. Its mixture with milk facilitates its consumption. MCTs can be included in jellies, soups, mashed potatoes, sauces, and pastries. Consumption of mixtures of MCTs and milk before sleeping can help ketosis at night (6).
Usually, $10 \%$ of energy comes from proteins and 15-19\% from carbohydrates (49). Neal et al. (29) compared KD and MCT diets in a randomized and controlled study. No difference was found between 45 children who received the classic KD diet and 49 children who received the MCT diet ( $45 \%$ were patients with refractory epilepsy) for 3, 6 and 12 months. Patients with seizure reduction rates more than $50 \%$ and $90 \%$ were similiar without significant difference between the groups. In another study, 16 children with refractory epilepsy received the MCT diet and seizure rates reduced by more than $50 \%$ in $64.3 \%$ of the children, and $28.6 \%$ of the children became seizure free (52).

The MCT diet allows more carbohydrate intake, and as a result, it has more taste compared with the classic diet. Also, the MCT diet allows consumption of more types of vegetables and fruits and larger portions compared with classic KD. Consumption of various and multiple foods results in less micronutrient need and better growth in children compared with KD. Also, kidney stones, hypoglycemia, ketoacidosis, constipation, low bone mineral density, and growth retardation are less frequently seen with the MCT diet. However, the MCT diet is more expensive than classic $\mathrm{KD}(4,53)$.

\section{Modified Atkins Diet}

The MAD was developed at the Johns Hopkins Hospital as being less limiting and allows more taste than classic KD (54). MAD allows higher lipid intake and limits carbohydrate intake (55). Protein and energy intake are not limited in MAD, unlike in classic KD $(48,55)$. Fasting is not required at initiation. The contents of MAD are: $60 \%$ lipid, $30 \%$ protein, and $10 \%$ carbohydrate (55). There is no need to plan or limit meals $(55,56)$. Carbohydrate limitation is $10 \mathrm{~g} / \mathrm{d}$ at initiation, then 15 $\mathrm{g} / \mathrm{d}$ the next month, and up to $20-30 \mathrm{~g} / \mathrm{d}$ due to seizure control and toleration (56). The ketogenic ratio in MAD is 0.9:1 (fat: carbohydrate + protein), which is lower than classic 4:1 KD. MAD was used for the first time in 20 children with refractory epilepsy and seizures were reduced in 13 by more than $50 \%$, and in 7 by more than $90 \%$ (57). In another study, MAD was used in 32 children with refractory epilepsy for one month and seizures were reduced in 24 by more than $50 \%$, and in 11 by

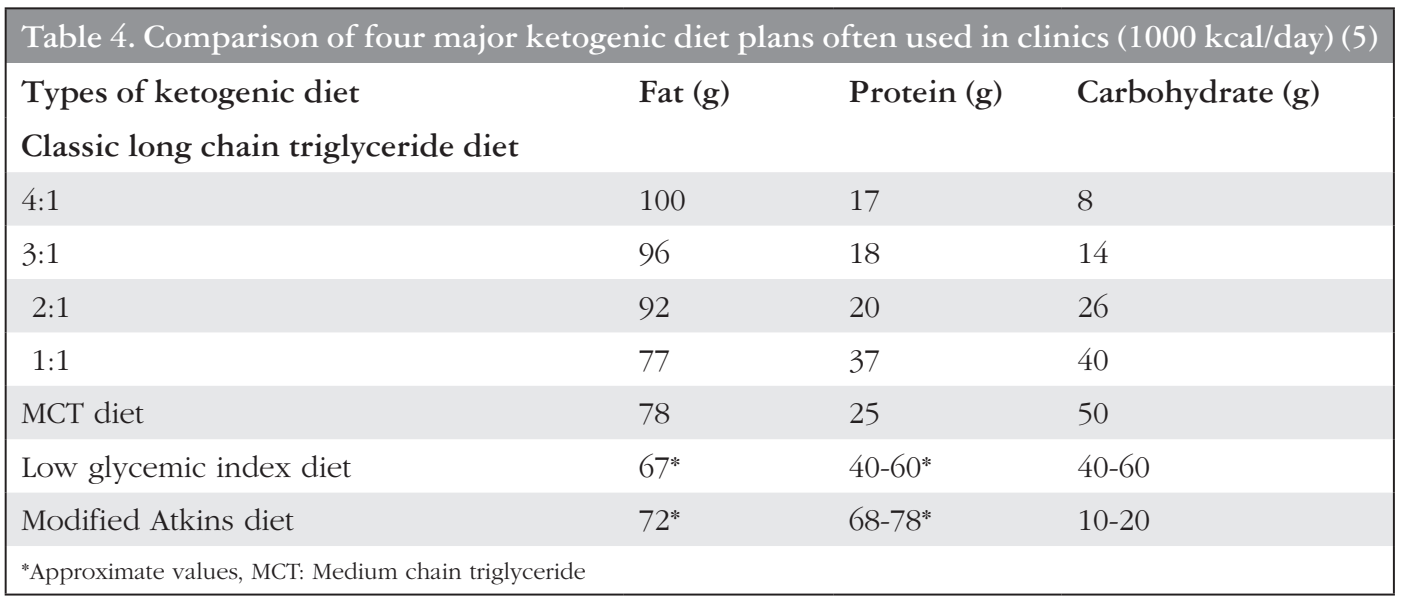


more than $90 \%$ (58). Very few adverse events were reported because MAD and LDL cholesterol levels were not increased in the pediatric and adult patients in the Johns Hopkins Hospital $(30,57)$. Blood urea nitrogen levels are elevated due to high protein intake but there is no elevation in serum creatinine levels (59). There is still uncertanity about the efficacy of MAD and more studies are needed (56).

\section{Low Glycemic Index Diet}

The LGI diet was used in 2005 for the first time in epilepsy (15). Carbohydrate intake is restricted to $40-60 \mathrm{~g} / \mathrm{d}, 60 \%$ of the energy is gathered from fat and $20-30 \%$ from protein (48). The glycemic index of all carbohydrates in the meal is kept below $50(48,49)$. The ratio in the LGI diet is similiar to $1: 1 \mathrm{KD}$ (15). Specific meal plans are not arranged and recommendations are made according to individual choices. The distribution of protein, carbohydrate, and fat in meals and meal samples should be arranged by a dietitian $(15,48)$. Nutrients with a high glycemic index (e.g., watermelon, potatoes) cause significant elevation in blood glucose levels, whereas nutrients with LGIT (apple, cucumber, full-grain bread) lower postprandial glucose and insulin levels (60). In a study, 76 children were given an LGI diet for 1, 3, 6, 9 and 12 months. Seizures were reduced by more than $50 \%$ in $42 \%$, $50 \%, 54 \%, 64 \%$, and $66 \%$ of the children, respectively (61). In another study, seizures were reduced by more than $90 \%$ in half of 20 children with refractory epilepsy who were given the LGI diet (15). Easy meal preparation, no need for detailed planning for meals, and no need to calculate the portions by grams make the LGI diet feasible. The low fat and free carbohydrate content make the LGI diet more tasty. Patients outside home can reach food without mandatory choosing of special meals, which causes less psychosocial problems (61). A comparison of the four major KD plans most often used in clinics is shown in Table 4 (5).

\section{Supplement Use in Ketogenic Diet}

Only balanced nutrition can provide intake of sufficent vitamins and minerals, but in a $\mathrm{KD}$, intake of vegetables, fruits, enriched grains, and calcium-containing nutrients is limited. Vitamin B supplementation is needed in particular (62). Calcium intake with foods is reduced and vitamin D levels are decreased in KD. Vitamin D and calcium supplementations are needed. Use of multivitamins and minerals that do not contain or only contain very few carbohydrates are advised $(5,62)$. Carnitine supplementation, which may cause serious systemic complications including secondary hypocarnitinemia, cardiomyopathy, and hepatitis, is controversial in most centers (63). More studies on the effects of carnitine supplementation in $\mathrm{KD}$ are needed (2).

\section{Adverse Events of the Ketogenic Diet}

There are some adverse events related with $\mathrm{KD}$, which are reported at initiation of the diet or during the diet. Dehydration can be seen at the initiation of the diet. During fasting, low blood glucose levels are usually asymptomatic. If low blood glucose levels cause symptoms, 30 cc orange juice can be given and glucose levels are followed. Vomiting is common at initiation of the diet (4).

$\mathrm{KD}$ is an important factor that causes growth retardation in children. Weight gains and heights are reported below expected values in children who receive this kind of diet (64). Growth requires sufficient energy intake. If the protein/energy ratio is kept at level of $1.5 \mathrm{~g} / 100 \mathrm{kcal}$, growth retardation can be avoided (65).

Gastrointestinal dysmotility is another adverse event of KD. $\mathrm{H} 2$ receptor blockers and proton pump inhibitors can be used for gastroesophageal reflux. Also, families should be informed about the predispositon to constipation and eating vegetables containing multiple fibers, sufficient water intake, and if needed, using laxatives that do not contain carbohydrates are recommended (2).

Kidney stones are seen in $3-10 \%$ of patients receiving $\mathrm{KD}$, sufficient hydration prevents the production of kidney stones (66). In cases of hematuria, calciuria or pain, kidney sonography can be performed and creatinine and spot urine calcium are helpful in follow-up. Recent studies showed that oral potassium citrate caused a significant decrease in the prevalence of kidney stones in children receiving KD (3.2-10\%) (67).

Serum levels of triglyceride and cholesterol may be increased, especially in the first 6 months of KD and should be followed up (4). Kwiterovich et al. (68) studied the effects of KD on lipid profile and showed that total cholesterol, LDL, VLDL, and triglyceride levels were increased, and HDL levels were decreased at the end of 6 months. Another study showed that KD could be performed succesfully in children with hyperlipidemia (69).

Antiepileptic drugs can decrease the absorption of calcium by affecting vitamin D levels and also can cause rickets and osteomalasia by directly affecting bone turnover. KD prevents falls by reducing seizure frequency and also prevents the occurence of bone fractures by reducing the use of antiepileptic drugs. However, long-term KD may cause a predisposition to osteopenia (70).

Nausea, vomiting, hypoglycemia and lethargy due to severe ketoasidosis can be seen in the acute period of $\mathrm{KD}$, and constipation, weight loss, insufficiencies of vitamins and minerals (vitamin D, Se, Ca), pancreatitis, kidney stones, prolongation of the QT interval, cardiomyopathy, short stature, osteopenia, decrease in albumin and carnitine levels, and abnormalities of lipid profile can be seen in thre chronic period of KD (10).

\section{Use of the Ketogenic Diet in the Future}

KD can be neuroprotective in neurologic disorders characterized by neurodegeneration or metabolic disturbances (71). Clinical studies on Alzheimer's disease, amyotrophic lateral sclerosis, migraine, and brain tumors are ongoing $(5,72)$. The use of KD in non-epileptic conditions including otism, bipolar disorder, depression, diabetes mellitus, narcolepsy, obesity, stroke, traumatic brain injury, Parkinson's disease, sleep disorders, and schizophrenia have been reported $(5,73)$. KD has beneficial effects on other neurologic diseases as it has on epilepsy, but the mechanisms of action are not known (74). 


\section{Conclusion and Recommendations}

Most patients with epilepsy respond well to pharmacologic treatment, but $20-30 \%$ are resistant to antiepileptic drugs. KD reduces seizure frequency of children with refractory epilepsy and has better efficacy than most antiepileptic drugs. Some epileptologists argue that KD is one of the most effective treatments in epilepsies of childhood. Limited meal patterns, supplement need, biochemical findings, and adverse events limit KD's sustainability. Giving education to families is required for a long time and training for feeding is important for the success of the diet. Patients (and their families) who receive KD, should be interested and have a high level of education. Although $\mathrm{KD}$ is effective, it is hard for patients and their families to continue the diet because of difficulties in compliance to the diet. Dietitians and neurologists should be aware of KD and increase its use. For potential adverse events, patients should be controlled by dietitians, physicians, and psychologists if needed during treatment. The parents of the patients should be trained for the diet and checked periodically. Also, the limitations of $\mathrm{KD}$ are accompanied by psychosocial problems. Eating different foods than peers may cause social isolation. Alternative diet lists should be developed for KD to promote the diversity of foods and facilitate KD's applicability. Future studies are needed to evaluate KD's long-term effects.

\section{Diet Plan for $1400 \mathrm{kcal}$ and 4:1 Ketogenic Diet}

After evaluating the food consumption, body weight and protein needs, a diet that provides $1400 \mathrm{kcal}$ was arranged then a sample menu was prepared for seven-year-old a girl (normal body weight).

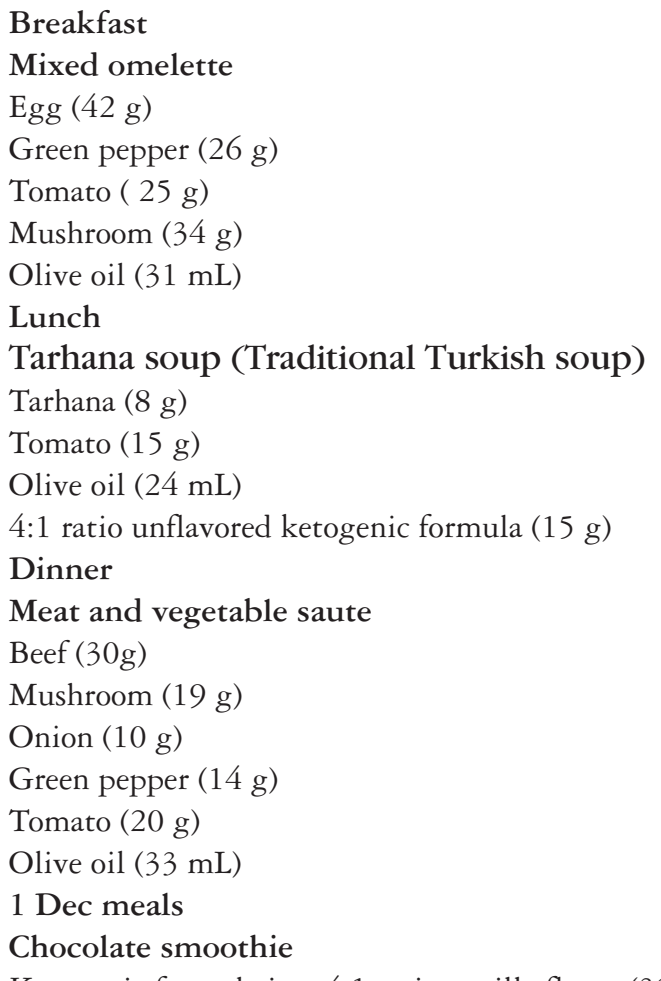

Ketogenic formula in a 4:1 ratio vanilla flavor $(32 \mathrm{~g})$
Cacao $(3 \mathrm{~g})$

Olive oil $(12 \mathrm{~mL})$

Natural sweetener ( $4 \mathrm{~g}$ )

Ethics

Peer-review: Externally peer-reviewed.

Authorship Contributions

Concept: G.Ö.U., N.Ş., Design: G.Ö.U., N.Ş., Data Collection or Processing: G.Ö.U., N.Ş., Analysis or Interpretation: G.Ö.U., N.Ş., Literature Search: G.Ö.U., Writing: G.Ö.U.

Conflict of Interest: No conflict of interest was declared by the authors.

Financial Disclosure: The authors declared that this study received no financial support.

\section{References}

1. Franzon RC, Montenegro MA, Guimarães CA, Guerreiro CA, Cendes F, Guerreiro MM. Clinical, electroencephalographic, ad behavioral features of temporal lobe epilepsy in childhood. J Child Neurol 2004;19:418-423.

2. Kossoff EH, Zupec-Kania BA, Amark PE, et al. Optimal clinical management of children receiving the ketogenic diet: recommendations of the International Ketogenic Diet Study Group. Epilepsia 2009;50:304-317.

3. Bailey EE, Pfeifer HH, Thiele EA. The use of diet in the treatment of epilepsy. Epilepsy Behav 2005;6:4-8.

4. Sharma S, Jain P. The ketogenic diet and other dietary treatments for refractory epilepsy in children. Ann Indian Acad Neurol 2014;17:253-258.

5. Kossoff EH, Zupec-Kania BA, Rho JM. Ketogenic diets: an update for child neurologists. J Child Neurol 2009;24:979-988.

6. Shaw V, Lawson M. Clinical Paediatric Dietetics. 3rd ed. British Journal of Nutrition. pp. 604;2007. Available from: https:// www.cambridge.org/core/services/aop-cambridge-core/content/ view/3A4DB36B5217C01C4FDAFD04971C0C9E/S0007114507871698a. $\mathrm{pdf} /$ div-class-title-target-target-shaw-v-and-lawson-m-editors-span-classitalic-clinical-paediatric-dietetics-span-3rd-ed-oxford-blackwell-publishing-2007-59-50-hardback-pp-604-isbn-

7. Bough KJ, Rho JM. Anticonvulsant mechanisms of the ketogenic diet. Epilepsia 2007;48:43-58.

8. Masino SA, Rho JM. Mechanisms of ketogenic diet action. 4th ed. Bethesda. National Center for Biotechnology Information (US), 2012.

9. Rubenstein JE, Kossoff EH, Pyzik PL, Vining EP, McGrogan JR, Freeman JM. Experience in the use of the ketogenic diet as early therapy. J Child Neurol 2005;20:31-34.

10. Dhamija R, Eckert S, Wirrell E. Ketogenic diet. Can J Neurol Sci 2013;40:158167.

11. Thavendiranathan P, Mendonca A, Dell C, et al. The MCT ketogenic diet: effects on animal seizure models. Exp Neurol 2000;161:696-703.

12. Dutton SB, Sawyer NT, Kalume F, et al. Protective effect of the ketogenic diet in Scn1a mutant mice. Epilepsia 2011;52:2050-2056.

13. Bough KJ, Yao SG, Eagles DA. Higher ketogenic diet ratios confer protection from seizures without neurotoxicity. Epilepsy Res 2000;38:15-25.

14. Chen W, Kossoff EH. Long-term follow-up of children treated with the modified Atkins diet. J Child Neurol 2012;27:754-758.

15. Pfeifer HH, Lyczkowski DA, Thiele EA. Low glycemic index treatment: implementation and new insights into efficacy. Epilepsia 2008;49(Suppl 8):42-45.

16. Coppola G, Veggiotti P, Cusmai R, et al. The ketogenic diet in children, adolescents and young adults with refractory epilepsy: an Italian multicentric experience. Epilepsy Res 2002;48:221-227.

17. Klein P, Janousek J, Barber A, Weissberger R. Ketogenic diet treatment in adults with refractory epilepsy. Epilepsy Behav 2010;19:575-579. 
18. Taha AY, Ryan MA, Cunnane SC. Despite transient ketosis, the classic highfat ketogenic diet induces marked changes in fatty acid metabolism in rats. Metabolism 2005;54:1127-1132.

19. Bromfield E, Dworetzky B, Hurwitz S, et al. A randomized trial of polyunsaturated fatty acids for refractory epilepsy. Epilepsy Behav 2008;12:187-190.

20. Auvin S. Fatty acid oxidation and epilepsy. Epilepsy Res 2012;100:224-228.

21. DeGiorgio CM, Miller P, Meymandi S, Gornbein JA. n-3 fatty acids (fish oil) for epilepsy, cardiac risk factors, and risk of SUDEP: clues from a pilot, doubleblind, exploratory study. Epilepsy Behav 2008;13:681-684.

22. Sullivan PG, Rippy NA, Dorenbos K, Concepcion RC, Agarwal AK, Rho JM. The ketogenic diet increases mitochondrial uncoupling protein levels and activity. Ann Neurol 2004;55:576-580.

23. Chmiel-Perzyńska I, Kloc R, Perzyński A, Rudzki S, Urbańska EM. Novel aspect of ketone action: $\beta$-hydroxybutyrate increases brain synthesis of kynurenic acid in vitro. Neurotox Res 2011;20:40-50.

24. Lefevre F, Aronson N. Ketogenic diet for the treatment of refractory epilepsy in children: A systematic review of efficacy. Pediatrics 2000;105:46.

25. Levy RG, Cooper PN, Giri P, Weston J. Ketogenic diet and other dietary treatments for epilepsy. The Cochrane Library 2012.

26. Keene DL. A Systematic Review of the Use of the Ketogenic Diet in Childhood Epilepsy. Pediatr Neurol 2006;35:1-5.

27. Henderson CB, Filloux FM, Alder SC, Lyon JL, Caplin DA. Efficacy of the ketogenic diet as a treatment option for epilepsy: meta-analysis. J Child Neurol 2006;21:193-198.

28. Neal EG, Chaffe H, Schwartz RH, et al. The ketogenic diet for the treatment of childhood epilepsy: a randomised controlled trial. Lancet Neurol 2008;7:500506.

29. Neal EG, Chaffe H, Schwartz RH, et al. A randomized trial of classical and medium-chain triglyceride ketogenic diets in the treatment of childhood epilepsy. Epilepsia 2009;50:1109-1117.

30. Kossoff EH, Turner Z, Bluml RM, Pyzik PL, Vining EP. A randomized, crossover comparison of daily carbohydrate limits using the modified Atkins diet. Epilepsy Behav 2007;10:432-436.

31. Seo JH, Lee YM, Lee JS, Kang HC, Kim HD. Efficacy and tolerability of the ketogenic diet according to lipid: nonlipid ratios--comparison of 3:1 with 4:1 diet. Epilepsia 2007;48:801-805.

32. Suo C, Liao J, Lu X, et al. Efficacy and safety of the ketogenic diet in Chinese children. Seizure 2013;22:174-178.

33. Sharma S, Gulati S, Kalra V, Agarwala A, Kabra M. Seizure control and biochemical profile on the ketogenic diet in young children with refractory epilepsy--Indian experience. Seizure 2009;18:446-449.

34. Thammongkol S, Vears DF, Bicknell-Royle J, et al. Efficacy of the ketogenic diet: which epilepsies respond? Epilepsia 2012;53:55-59.

35. Caraballo RH, Flesler S, Armeno M, et al. Ketogenic diet in pediatric patients with refractory focal status epilepticus. Epilepsy Res 2014;108:1912-1916.

36. Dressler A, Trimmel-Schwahofer P, Reithofer E, et al. The ketogenic diet in infants--Advantages of early use. Epilepsy Res 2015;116:53-58.

37. Caraballo R, Vaccarezza M, Cersósimo R, et al. Long-term follow-up of the ketogenic diet for refractory epilepsy: Multicenter Argentinean experience in 216 pediatric patients. Seizure 2011;20:640-645.

38. Hartman AL, Vining EP. Clinical aspects of the ketogenic diet. Epilepsia 2007;48:31-42.

39. Kossoff EH. More fat and fewer seizures: dietary therapies for epilepsy. Lancet Neurol 2004;3:415-420.

40. Bergqvist AG, Schall JI, Gallagher PR, Cnaan A, Stallings VA. Fasting versus gradual initiation of the ketogenic diet: a prospective, randomized clinical trial of efficacy. Epilepsia 2005;46:1810-1819.

41. Freeman J, Veggiotti P, Lanzi G, Tagliabue A, Perucca E; Institute of Neurology IRCCS C. Mondino Foundation. The ketogenic diet: From molecular mechanisms to clinical effects. Epilepsy Res 2006;68:145-180.

42. Hartman AL, Rubenstein JE, Kossoff EH. Intermittent fasting: a "new" historical strategy for controlling seizures? Epilepsy Res 2013;104:275279
43. Stafstrom CE, Rho J. Epilepsy and the ketogenic diet. Springer Science \& Business Media, 2004.

44. Wirrell EC. Ketogenic ratio, calories, and fluids: do they matter? Epilepsia 2008;49(Suppl 8):17-19.

45. Raju KN, Gulati S, Kabra M, et al. Efficacy of 4:1 (classic) versus 2.5:1 ketogenic ratio diets in refractory epilepsy in young children: A randomized open labeled study. Epilepsy Res 2011;96:96-100.

46. Nylen K, Likhodii S, Abdelmalik PA, Clarke J, Burnham WM. A comparison of the ability of a 4:1 ketogenic diet and a 6.3:1 ketogenic diet to elevate seizure thresholds in adult and young rats. Epilepsia 2005;46:1198-1204.

47. Huttenlocher PR. Ketonemia and seizures: metabolic and anticonvulsant effects of two ketogenic diets in childhood epilepsy. Pediatric Res 1976;10:536540.

48. Liu YM, Wang HS. Medium-chain triglyceride ketogenic diet, an effective treatment for drug-resistant epilepsy and a comparison with other ketogenic diets. Biomed J 2013;36:9-15.

49. Miranda MJ, Turner Z, Magrath G. Alternative diets to the classical ketogenic diet--Can we be more liberal? Epilepsy Res 2012;100:278-285.

50. Stafstrom CE. Dietary approaches to epilepsy treatment: old and new options on the menu. Epilepsy Curr 2004;4:215-222.

51. Neal EG, Cross JH. Efficacy of dietary treatments for epilepsy. J Human Nutr Diet 2010;23:113-119.

52. Chomtho K, Suteerojntrakool O, Chomtho S. Effectiveness of Medium Chain Triglyceride Ketogenic Diet in Thai Children with Intractable Epilepsy. J Med Assoc Thai 2016;99:159-165.

53. Liu YM. Medium-chain triglyceride (MCT) ketogenic therapy. Epilepsia 2008;49(Suppl 8):33-36.

54. Kumada T, Miyajima T, Oda N, Shimomura H, Saito K, Fujii T. Efficacy and tolerability of modified Atkins diet in Japanese children with medicationresistant epilepsy. Brain Dev 2012;34:32-38.

55. Sharma S, Jain P. The modified Atkins diet in refractory epilepsy. Epilepsy Res Treat 2014;404202:1-6.

56. Kossoff EH, Dorward JL. The modified Atkins diet. Epilepsia 2008;49(Suppl 8):37-41.

57. Kossoff EH, McGrogan JR, Bluml RM, Pillas DJ, Rubenstein JE, Vining EP. A modified Atkins diet is effective for the treatment of intractable pediatric epilepsy. Epilepsia 2006;47:421-424.

58. Kossoff EH, Dorward JL, Turner Z, Pyzik PL. Prospective study of the modified atkins diet in combination with a ketogenic liquid supplement during the initial month. J Child Neurol 2011;26:147-151.

59. Kossoff EH, Rowley H, Sinha SR, Vining EP. A prospective study of the modified Atkins diet for intractable epilepsy in adults. Epilepsia 2008;49:316319.

60. Bell SJ, Sears B. Low-glycemic-load diets: impact on obesity and chronic diseases.Crit Rev Food Sci Nutr 2003;43:357-377.

61. Muzykewicz DA, Lyczkowski DA, Memon N, Conant KD, Pfeifer HH, Thiele EA. Efficacy, safety, and tolerability of the low glycemic index treatment in pediatric epilepsy. Epilepsia 2009;50:1118-1126.

62. Bergqvist AG, Schall JI, Stallings VA. Vitamin D status in children with intractable epilepsy, and impact of the ketogenic diet. Epilepsia 2007;48:6671.

63. Berry-Kravis E, Booth G, Sanchez AC, Woodbury-Kolb J. Carnitine levels and the ketogenic diet. Epilepsia 2001;42:1445-1451.

64. Peterson SJ, Tangney CC, Pimentel-Zablah EM, Hjelmgren B, Booth G, Berry-Kravis E. Changes in growth and seizure reduction in children on the ketogenic diet as a treatment for intractable epilepsy. J Am Diet Assoc 2005;105:718-725.

65. Nation J, Humphrey M, MacKay M, Boneh A. Linear growth of children on a ketogenic diet: does the protein-to-energy ratio matter? J Child Neurol 2014;29:1496-1501.

66. Kossoff EH, Pyzik PL, Furth SL, Hladky HD, Freeman JM, Vining EP. Kidney Stones, Carbonic Anhydrase Inhibitors,and the Ketogenic Diet. Epilepsia 2002;43:1168-1171.

67. Sampath A, Kossoff EH, Furth SL, Pyzik PL, Vining EP. Kidney Stones and the Ketogenic Diet:Risk Factors and Prevention. J Child Neurol 2007;22:375-378. 
68. Kwiterovich PO Jr, Vining EP, Pyzik P, Skolasky R Jr, Freeman JM. Effect of a high-fat ketogenic diet on plasma levels of lipids, lipoproteins, and apolipoproteins in children. JAMA 2003;290:912-920.

69. Liu YM, Lowe H, Zak MM, Kobayashi J, Chan VW, Donner EJ. Can children with hyperlipidemia receive ketogenic diet for medication-resistant epilepsy? J Child Neurol 2013;28:479-483.

70. Bergqvist AG. Long-term monitoring of the ketogenic diet: Do's and Don'ts. Epilepsy Res 2012;100:261-266.
71. Barañano KW, Hartman AL. The ketogenic diet: uses in epilepsy and other neurologic illnesses. Curr Treat Options Neurol 2008;10:410-419.

72. Kossoff EH, Hartman AL. Ketogenic diets: new advances for metabolismbased therapies. Curr Opin Neurol 2012;25:173-178.

73. Freeman JM, Kossoff EH, Hartman AL. The ketogenic diet: one decade later Pediatrics 2007;119:535-543

74. Polsky D, Weiner J, Bale JF Jr, Ashwal S, Painter MJ. Specialty care by child neurologists A workforce analysis. Neurology 2005;64:942-948. 